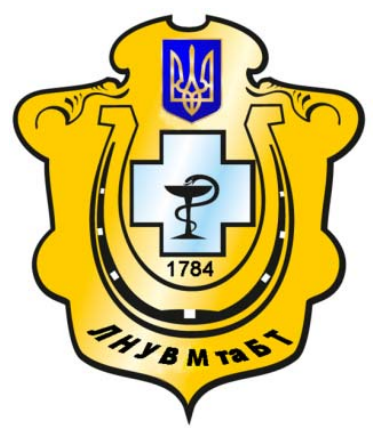

Науковий вісник Львівського національного університету ветеринарної медицини та біотехнологій імені С.3. Гжицького

Scientific Messenger of Lviv National University of Veterinary Medicine and Biotechnologies named after S.Z. Gzhytskyj

doi:10.15421/nvlvet7745

ISSN 2518-7554 print

ISSN 2518-1327 online

$\underline{\text { http://nvlvet.com.ua/ }}$

УДК 619:578:579.62:636.4:577.2

\title{
Експериментальне зараження поросят вірусом епідемічної діареї свиней
}

\author{
Д.М. Масюк, О.І. Сосницький, А.В. Кокарєв, С.Г. Коляда \\ plppm@ua.fm
}

Дніпропетровський державний аграрно-економічний університет, вул. Ворошилова, 25, м. Дніпро, 49600, Україна;

\begin{abstract}
Було проведено зараження неонатальних безмолозивних поросят у периу добу їх життя суспензією вірусу ЕДС, отриманого раніме від поросят, хворих на ЕДС. Діагноз на ЕДС у поросят-донорів вірусу ЕДС був вставлений комплексним методом за клініко-епізоотологічними показниками і підтверджений ідентифікачією PEDV методом PCR-RT за допомогою тест-системи «EZ-RED / TGE / PDCoV MPX 1.0 Real time RT-PCR» фiрми Tetracore (США) на ампліфікаторі CFX 96 Real-Time System фірми BIO RAD (США). Гомогенат тонкого кишечнику поросят-донорів PEDV, готували на блендері для PCR у вигляді густого смузі від 18 трупів тварин, заморожували при $-18{ }^{\circ} \mathrm{C}$ без додавання кріоконсервантів $i$ зберігали 359 діб. Перед зараженням поросят смузі розморожували $i$ методом PCR-RT визначили концентрацію вірусу в геномеквівалентах (Г.Е.) без кількісного встановлення життєздатних віріонів збудника. Для біопроби відбирали 20 аналогових неонатальних безмолозивних поросят, розділяли їх на 3 дослідні групи (1 група - 5 поросят, 2 група - 5 поросят i 3 група - 7 поросят) та одну контрольну (3 поросяти). Дослідних поросят рег оs заражали вірусвмісною суспензією, з концентрацією

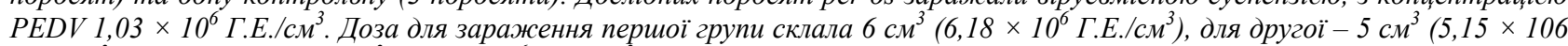

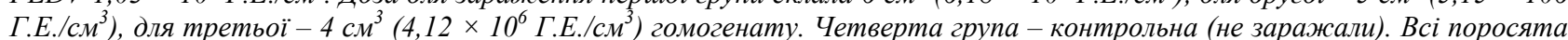
перебували в ідентичних умовах, які повністю відповідають фізіологічним потребам організму. 317 заражених поросят лише 2 поросят заразилися РЕDV. ЕДС було підтверджено лабораторними методами. При бактеріологічному дослідженні внутрішніх органів поросят, що вийшли з експерименту як дослідних, так і контрольної груп, був діагностований колібактеріоз. У контрольній групі була ізольована з серия і кишечнику непатогенна для білих мишей E. coli. Bid поросят 1 i 2 дослідних груп була виділена непатогенна для білих мишей E. coli, тобто встановлений колібактеріоз; у 2 дослідній групі у одного поросяти виявили гемолітичну кишкову паличку; у 3 дослідній групі з внутрішніх органів поросят спільно з непатогенною для колишніх мишей кишкової палички ізолювали Klesiella spp., тобто діагностували мікс-інфекиію - колібактеріоз $i$ клебсієльоз. 3 кишечнику всіх дослідних і контрольних поросят не виділили фізіологічно корисної індигенної мікрофлори аерококів, молочно-кислих- $і$ біфідобактерій, а висіяли гнильну факультативно-анаеробну спорову і неспорову мікрофлору.

Ключові слова: ЕДС, неонатальні поросята, зараження PEDV, водяниста діарея, патогенез, PCR-RT, кількісна характеристика РEDV, кишкова мікрофлора.
\end{abstract}

\section{Экспериментальное заражение поросят вирусом эпидемической диареи свиней}

\author{
Д.Н. Масюк, А.И. Сосницкий, А.В. Кокарев, С.Г. Коляда \\ plppm@ua.fm
}

Днепропетровский государственный аграрно-экономический университет, ул. Ворошилова, 25, г. Днепр, 49600, Украина

Было проведено заражение неонатальных безмолозивних поросят в первые сутки их жизни суспензией вируса ЭДС, полученного ранее от поросят больных ЭДС. Диагноз ЭДС у поросят-доноров вируса ЭДС был установлен комплексным методом по клинико-эпизоотологическим показателями и подтвержден идентификацией PEDV методом PCR-RT с помощью

\section{Citation:}

Masiuk, D., Sosnitskiy, A., Kokarev, A., Koliada, S. (2017). Experimental infection of pigs porcine epidemic diarrhea virus. Scientific Messenger LNUVMBT named after S.Z. Gzhytskyj, 19(77), 208-213. 
тест-системы «EZ-RED/TGE/PDCoV MPX 1.0 Real time RT-PCR» фирмы Tetracore (США) в амплификаторе CFX 96 RealTime System фирмы BIO RAD (США). Гомогенат тонкого кишечника поросят-доноров PEDV, готовили на блендере для PCR в виде густого смузи от 18 трупов животных, замораживали при $-18{ }^{\circ} \mathrm{C}$ без добавления криоконсервантов и хранили 359 суток. Перед заражением поросят смузи разморажсивали и методом PCR-RT определяли концентрацию вируса в геном-эквивалентах (Г.Е.) без количественного установления жизнеспособных вирионов возбудителя. Для биопробы отбирали 20 аналоговых неонатальных безмолозивних поросят, делили их на 3 опытные группы (1 группа - 5 поросят, 2 группа - 5 поросят и 3 группа - 7 поросят) и одну контрольную (3 поросенка). Опытных поросят рег ов заражали вирусосодержащей суспензией, с концентрацией PEDV $1,03 \times 10^{6}$ Г.Е./см. Доза для заражения первой группы составила 6 см3 $\left(6,18 \times 10^{6}\right.$

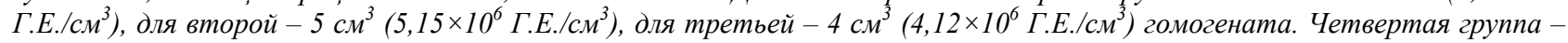
контрольная (не заражали). Все поросята находились в идентичных условиях, которые полностью соответствуют физиологическим потребностям организма. Из 17 зараженных поросят только 2 поросенка заразились РЕDV, что было подтверждено лабораторными методами. При бактериологическом исследовании внутренних органов поросят, вышедших из эксперимента как опытных, так и контрольной групп, был диагностирован колибактериоз. В контрольной группе была изолирована из сердиа и кишечника непатогенная для белых мышей E. coli. Oт поросят 1 и 2 опытных групп была выделена непатогенная для белых мышей E. coli, то есть установлен колибактериоз; во 2 опытной группе у одного поросенка обнаружсили гемолитическую кишечную палочку; в 3 опытной группе из внутренних органов поросят совместно с непатогенной для белых мышей кишечной палочкой изолировали Klesiella spp., то есть диагностировали микс-инфекиию - колибактериоза и клебсиеллеза. Из кишечника всех опытных и контрольных поросят не выделили физиологически полезной индигенной микрофлоры - аэрококков, молочно кислых- и бифидобактерий, а высеяли гнилостную факультативно-анаэробную споровую и неспоровую микрофлору.

Ключевые слова: ЭДС, неонатальные поросята, заражение PEDV, водянистая диарея, патогенез, PCR-RT, количественная характеристика PEDV, кишечная микрофлора.

\title{
Experimental infection of pigs porcine epidemic diarrhea virus
}

\author{
D. Masiuk, A. Sosnitskiy, A. Kokarev, S. Koliada \\ plppm@ua.fm
}

Dnipropetrovsk state agrarian-economic university,
Voroshilov Str., 25, Dnepr, 49600, Ukraine;

\begin{abstract}
There were infected neonatal piglets in the first days of their lives PED virus suspension derived from pigs previously PED patients. Diagnosis for PED in piglets donor virus PED was inserted complex method for clinical and epizootic performance and confirmed the identification PEDV by PCR-RT using the test system «EZ-RED/TGE/PDCoV MPX 1.0 Real time RT-PCR» company Tetracore (USA) Thermocyclers CFX 96 Real-Time System company BIO RAD (USA). Homogenate small intestine of pigs PEDV donor, prepared in a blender for PCR in a thick band of 18 animal carcasses, frozen at $-18{ }^{\circ} \mathrm{C}$ without cryopreservation and kept 359 days. Before infecting pigs and strip defrost by RT-PCR identified the concentration of the virus genome equivalents (GE) without establishing viable virions quantitative pathogen. For Sample 20 selected analog neonatal piglets, divided them into 3 experimental groups (group $1-5$ piglets, group $2-5$ piglets and group $3-7$ piglets) and one control (3 piglets). Research pigs infected per os virus-containing suspension with a concentration PEDV $1.03 \times 10^{6} \mathrm{GE} / \mathrm{cm}^{3}$. The dose for infection first group was $6 \mathrm{~cm} 3\left(6.18 \times 10^{6}\right.$ $\left.\mathrm{GE} / \mathrm{cm}^{3}\right)$, for the second $-5 \mathrm{~cm}^{3}\left(5,15 \times 10^{6} \mathrm{GE} / \mathrm{cm}^{3}\right)$, for the third $-4 \mathrm{~cm}^{3}\left(4.12 \mathrm{GE} \times 10^{6} / \mathrm{cm}^{3}\right)$ homogenate. The fourth group control (not infected). All the pigs were in identical conditions that fully meet the physiological needs of the body. Of the 17 infected pigs only 2 was infected PEDV. PED was confirmed by laboratory methods. In bacteriological examination of internal organs of pigs that came out of a research experiment and control group were diagnosed colibacteriosis. In the control group was isolated from heart and intestinal non-pathogenic for white mice E. coli. From pigs 1 and 2 research groups has been allocated to white mice nonpathogenic E. coli, is set colibacteriosis; 2 experimental group found in one pig hemolytic E. coli; 3 experimental group from the internal organs of pigs in conjunction with non-pathogenic for mice intestinal former cane isolated Klesiella spp., is diagnosed with mixed infection (E. coli, Klesiella spp.). From the intestine of experimental and control pigs do not identified beneficial microfloraaerococcus, lactobacteria, bifidobacteria and cultured putrefactive anaerobic spore facultative and non spore microflora.
\end{abstract}

Key words: PED, neonatal piglets infected PEDV, watery diarrhea, pathogenesis, PCR-RT, quantitative characterization PEDV, intestinal microflora.

\section{Вступ}

Епідемічна (епізоотична) діарея свиней (ЕДС, ЕДП, ТГС-подібне захворювання, PEDV) - контагіозне, гостроперебігаюче захворювання свиней, переважно неонатальних поросят з синдромом діареї та патогномонічним симптомом - водянистий пронос 3 масовою загибеллю поросят до тижневого віку (Sait Mizhnarodnoho Epizootychnoho Biuro).

Вперше ЕДС як окрему нозологічну одиницю описали в Англії в 1971 р. і з того часу збудник поширився на Європейському континенті, південно-східній Азії і північній Америці. Вірусну природу хвороби встановили Pensaert M.B. i Dobouck в 1989 р. Збудник викликає емерджентну інфекційну патологію у свиней $з$ великомасштабними спалахами летальної діареї у неонатальних поросят, при цьому уражаються свині різного віку, але в основному зі сприятливим прогнозом щодо життя (Carvajal et al., 2015).

Заходи боротьби з ЕДС засновані на недопущенні занесення та ірадикації вірусу, санітарноепізоотичних заходах 3 санації навколишнього середовища і ранньої індикації джерела інфекції. Найважливішим превентивним прийомом є суворе дотримання принципу «все зайнято - все пусто» і проведення ретельної та ефективної дезінфекції. Засоби специфі- 
чної профілактики представлені численними препаратами на ринку біопрепаратів, але багато хто з них має сумнівну репутацію, недостатньо апробовані та доведені їх протективні якості й біобезпека. Найбільш радикальний i примітивний метод профілактики створення лактогенного імунітету у неонатальних поросят шляхом зворотного згодовування вірусу в формі гомогенату тонкого кишечнику поросят, загиблих від ЕДС, свиноматкам перед опоросом, але це створює епізоотичну напруженість і вносить молекулярно-генетичні ризики (Song and Park, 2012; Dastjerdi et al., 2015).

Збудник ЕДС - РНК-вірус з оболонкою сімейства Coronaviridae, рід - Alphacoronavirus, вид - PEDV. Розрізняють два типи вірусу: перший тип вірусу викликає діарею у свиней на відгодівлі та дорослих свиней, а другий - тільки у поросят-сисунів. Вірус не створює перехресний імунітет 3 іншими кишковими коронавірусами, вражає тільки домашніх свиней. Основне джерело інфекції - хворі та перехворілі свині, виділення вірусу відбувається в основному з фекаліями, зараження здійснюється фекально-оральним шляхом у результаті прямого або непрямого контакту (фактори передачі) зі збудником та 3 молозивом, у вигляді імунних комплексів (Stevenson et al., 2013).

Мета роботи: встановити особливості патогенезу ЕДС у біопробі на безмолозивних неонатальних поросятах, визначити кількісний вміст збудника в Г.Е. у біологічному матеріалі від інфікованих поросят, а також встановити вплив кишкової мікрофлори на прояв синдрому діареї.

\section{Матеріал і методи дослідження}

Біологічне дослідження вірусу ЕДС на безмолозивних поросятах проводилося у віварії ФВМ Дніпропетровського ДАЕУ і лабораторії імунохімічних та молекулярно-генетичних досліджень НДЦ біобезпеки та екологічного контролю ресурсів АПК Дніпропетровського ДАЕУ згідно 3 темою «Визначення теоретичних аспектів епізоотичного процесу з урахуванням генетичних варіантів штамів вірусу епідемічної діареї свиней» (№ державної реєстрації 0117U004293).

Для біопроби за принципом аналогів методом випадкової безповторної вибірки підібрали 20 безмолозивних неонатальних поросят білої української породи від клінічно здорових свиноматок з господарства, неблагополучного щодо ЕДС.

Перший спалах ЕДС на підприємстві був зареєстрований в жовтні 2015 року, в результаті чого загинуло 98\% новонародженого молодняку поросят. Надалі спалахи коронавірусних ентеритів у поросят на підприємстві реєструються 3 періодичністю від 1 до 7 місяців.

Поросят поміщали у бокси, окремими групами в опалювальному приміщенні з оптимальною температурою повітря $\sim 30^{\circ} \mathrm{C}$, без протягів і різких перепадів температур. Для стабільної підтримки температури використовували інфрачервоні лампи.

Годівля здійснювалася за розробленою нами схемою: відразу після доставки поросят у віварій їм перорально ввели по $2 \mathrm{~cm}^{3}$ енергетика «Пігсейвер». Про- тягом експерименту поросят годували розведеним сухим молоком з інтервалом в 1-2 години.

Для ентерального зараження поросят використовували гомогенат кишечнику хворих поросят, який у вигляді смузі, отриманого за допомогою блендера для PCR, зберігався 12 місяців при $-18^{\circ} \mathrm{C}$ в замороженому вигляді без додавання кріопротекторів. Ex tempore зараженням поросят, смузі розморожували і в RT-PCR визначили концентрацію $P E D V$ у вихідному гомогенаті, яка складала $\approx 1,03 \times 106$ Г.Е. $/ \mathrm{cm}^{3}$ в біоматеріалі.

Вихідну суспензію в спадаючих кількостях згодували поросятам першої групи $-6 \mathrm{~cm}^{3}$, другої групи $5 \mathrm{~cm}^{3}$, третьої групи $-4 \mathrm{~cm}^{3}$. Свиней четвертої групи не заражали, вони залишалися чистими, інтактними.

За поросятами проводили постійне клінічне спостереження протягом 36 годин після зараження.

Протягом експерименту від поросят відбирали кров і фекалії через 1, 4, 8, 12, 24 і 36 годин після зараження. Зразки крові відбирали із орбітального венозного синуса (sinus venosus orbitalis)

По закінченні експерименту було проведено контрольний забій тварин для проведення патоморфологічного, гістологічного, ПЛР та бактеріологічного досліджень.

Для гістологічного дослідження використовували фрагмент тонкого кишечнику від поросят, що загинули, який фіксували у $10 \%$ розчині формаліну. Гістологічні зрізи проводили на санному мікротомі, після чого їх забарвлювали гематоксиліном та еозином. Дослідження гістологічних об'єктів проводили за допомогою апаратно-програмного комплексу з мікроскопу «Leica DM 1000», цифрової камери «Leica DFC 295» та програмного забезпечення «Leica Qwin 3.0» На гістологічних препаратах досліджували стан тонкої кишки за ураження вірусом ЕДС.

У зразках крові, фекаліях, фрагментах кишечнику і в матеріалі для зараження проводили індикацію $P E D V$ i його кількісну характеристику здійснювали методом PCR-RT за допомогою тест-системи «EZ-RED / TGE / PDCoV MPX 1.0 Real time RT-PCR» фірми Tetracore (США) на ампліфікаторі CFX 96 Real-Time System фірми BIO RAD (США).

Бактеріологічне дослідження вмісту шлунковокишкової трубки досліджуваних поросят включало індикацію та ідентифікацію мікробіонтів різного таксономічного підпорядкування. Для виділення аеробних бактерій використовували прості та збагачені поживні середовища, а саме: МПБ і МПА в нативному вигляді та 3 додаванням $10 \%$ сироватки крові, а також на переварі-Хотінгера (БПХ), серцевомозковому бульйоні, агарі Ендо, XLD агарі. Анаероби ізолювали посівом матеріалу в бульйон Кіта-Тароці і на кров'яний 5\% агар, плісняву та дріжджі - на агар Сабуро. Для індикації пробіотичної мікрофлори використовували посіви на прості середовища 3 додаванням крейди і гідролізованого казеїну.

Морфо-тинкторіальні і біохімічні властивості польових культур вивчали рутинними методами. Патогенність ідентифікованих добових культур мікроорганізмів визначали в біопробі на білих мишах. Бульйонну культуру досліджуваного мікроорганізму в 
обсязі 0,3 см³ вводили підшкірно 4 білим мишам живою масою 18-20 г.

\section{Результати та їх обговорення}

В результаті проведеного експерименту було відзначено розвиток діарейного синдрому у двох поросят 3 першої і одного поросяти 3 другої дослідної груп. Після проведення PCR-RT аналізу біологічного матеріалу було підтверджено наявність РНК вірусу ЕДС у поросят $з$ діарейним синдромом першої групи. Клінічні прояви розладу шлунково-кишкового тракту у поросяти другої групи було обумовлено патогенним впливом ентеропатогенної $\beta$-гемолітичної E. coli.

За підсумками клінічного спостереження за дослідними поросятами було встановлено, що через перші 18 годин після зараження у одного поросяти 3 першої дослідної групи було зареєстровано діарею. На 24 годину після зараження в першій дослідній групі діарея реєструвалася у двох поросят, а на 36 годину після інфікування діарейний синдром був зареєстрований у одного поросяти $з$ другої дослідної групи, при цьому залишилися 3 поросят $з$ першої групи, 4 з другої групи і всі тварини третьої і контрольної груп були клінічно здоровими.

Отже, перші прояви діарейного синдрому після зараження поросят вірусовмісним біологічним матеріалом були зареєстровані через 18 годин.

За результатами патологоанатомічного розтину поросят $з$ проявами діарейного синдрому першої дослідної групи (рис. 1) виявлені мікроскопічні зміни у тонкій кишці характерні для гострого катаральногеморагічного десквамаційного гастроентериту, серозно-катаральні запалення брижових лімфатічніх вузлів, яскраво виражене зневоднення та виснаження.

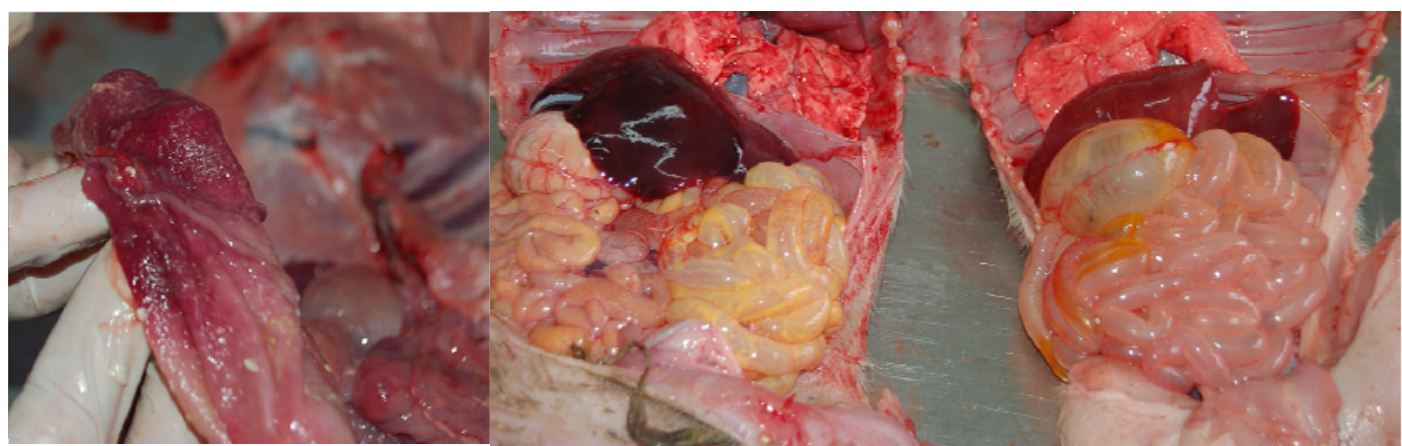

Рис. 1. Патоморфологічні зміни у неонатальних безмолозивних поросят з проявами діарейного синдрому першої дослідної групи

У тварини другої дослідної групи, у якої реєструвався синдрому діареї, виявлено виснаження, ознаки гострого катарально-геморагічного запалення тонкої кишки та гостре серозне запалення мезентеріальних лімфовузлів.

За мікроскопічного аналізу тонкої кишки від поросят 3 проявами діарейного синдрому першої дослідної групи (рис. 2) виявлено атрофію слизової оболонки, їі набряклість та інфільтрацію лейкоцитами.

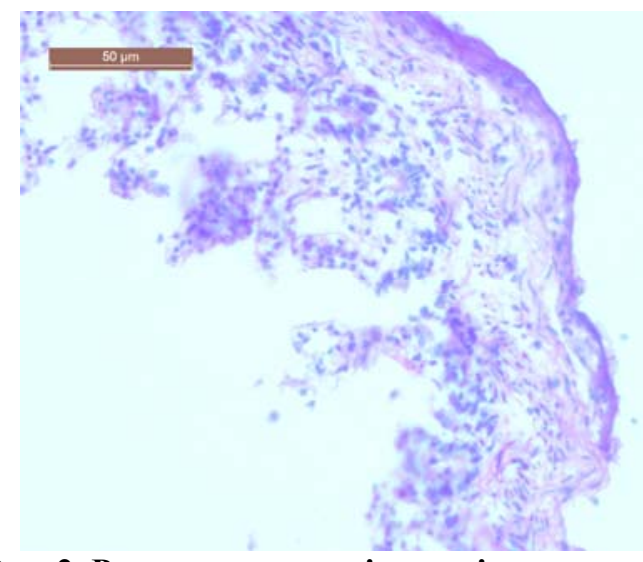

Рис. 2. Результати патогістологічного дослідження тонкої кишки у неонатальних безмолозивних поросят 3 проявами діарейного синдрому першої дослідної групи. Х20
Поверхневий та залозистий епітелій у стані дистрофії та некрозу. Десквамація кишкових епітеліоцитів. Набряк підслизової основи. Фрагментація, розпад та вакуолізація клітин м'язової оболонки. Пікноз та рексіс ядер. Крім цього, було виявлено інфільтрацію лімфоцитами i макрофагами, мікрокрововиливи у власній пластинці слизової оболонки ворсинок і підслизового шару. Такі ураження характерні для бактеріальної коліінфекції, що узгоджується з результатами бактеріологічного дослідження і підтверджує асоційований перебіг мікс-інфекції - PEDV + E. coli.

Отже, патологічні зміни тонкої кишки від неонатальних поросят 3 проявами діарейного синдрому першої дослідної групи на макро- та мікроскопічному рівні мають характерні ознаки гострого катаральнодесквамативного ентериту, що на тлі лейкоцитарної інфільтрації та мікровиливів у слизовій оболонці та ворсинках є типовою ознакою дії мікс-інфекції вірусних гастроентеритів свиней та коліінфекції.

Як видно з таблиці 1, РНК вірусу ЕДС виявлено лише у матеріалі від двох поросят $з$ проявами діарейного синдрому першої дослідної групи. Всі інші досліджувані зразки мали негативний результат, що свідчить про відсутність у них цільової послідовності РНК характерної для коронавірусу.

Слід відзначити, що вірус ЕДС реєструється у фекаліях поросят на 24 та 36 години після зараження, а у крові - на 36 годину після інфікування. Це свідчить про реплікацію вірусу ЕДС у кишечних ентероцитах 
поросят, що спричиняє порушення кишкової проникності та розвиток діарейного синдрому.

Отже, інфекційний процес за ЕДС характеризується екскрецією вірусу з фекаліями 324 години після інфікування та віремією з 36 години після зараження.

При бактеріологічному дослідженні внутрішніх органів поросят, що вийшли 3 досліду дослідних і контрольної груп, був діагностований колібактеріоз. У контрольній групі була ізольована із серця і кишеч- нику непатогенна для білих мишей E. coli. Від поросят 1 і 2 дослідних груп була виділена непатогенна для білих мишей E. coli, тобто встановлено колібактеріоз; у 2 дослідній групі в одного поросяти в пробі 3 серця виявили ще й гемолітичну кишкову паличку; в 3 дослідній групі із внутрішніх органів поросят спільно 3 непатогенною для колишніх мишей кишковою паличкою ізолювали Klesiella spp., тобто діагностували мікс-інфекцію - колібактеріоз і клебсієльоз.

Таблиия 1

Результати PCR-RT дослідження біологічного матеріалу від неонатальних безмолозивних поросят інфікованих вірусом $\operatorname{PEDV}(\mathrm{Ct})$

\begin{tabular}{|c|c|c|c|c|c|c|c|c|c|c|c|c|c|c|c|}
\hline \multirow{3}{*}{ група } & \multirow{3}{*}{$\begin{array}{l}\text { № } \\
\text { тв. }\end{array}$} & \multirow{3}{*}{$\begin{array}{c}\text { Прояви } \\
\text { діареї }\end{array}$} & \multicolumn{12}{|c|}{ Години після зараження } & \multirow{3}{*}{ Тонка кишка } \\
\hline & & & 1 & 4 & 8 & 12 & 24 & 36 & 1 & 4 & 8 & 12 & 24 & 36 & \\
\hline & & & \multicolumn{6}{|c|}{ Кров } & \multicolumn{6}{|c|}{ Фекалії } & \\
\hline \multirow{3}{*}{ K } & 1 & - & - & - & - & - & - & - & - & - & - & - & - & - & - \\
\hline & 2 & - & - & - & - & - & - & - & - & - & - & - & - & - & - \\
\hline & 3 & - & - & - & - & - & - & - & - & - & - & - & - & - & - \\
\hline \multirow{5}{*}{1} & 4 & + & - & - & - & - & - & 31,18 & - & - & - & - & 18,41 & 17,66 & 16,07 \\
\hline & 5 & - & - & - & - & - & - & - & - & - & - & - & - & - & - \\
\hline & 6 & - & - & - & - & - & - & - & - & - & - & - & - & - & - \\
\hline & 7 & + & - & - & - & - & - & 37,64 & - & - & - & - & 30,33 & 24,38 & 20,59 \\
\hline & 8 & - & - & - & - & - & - & - & - & - & - & - & - & - & - \\
\hline \multirow{5}{*}{2} & 9 & - & - & - & - & - & - & - & - & - & - & - & - & - & - \\
\hline & 10 & + & - & - & - & - & - & - & - & - & - & - & - & - & - \\
\hline & 11 & - & - & - & - & - & - & - & - & - & - & - & - & - & - \\
\hline & 12 & - & - & - & - & - & - & - & - & - & - & - & - & - & - \\
\hline & 13 & - & - & - & - & - & - & - & - & - & - & - & - & - & - \\
\hline \multirow{7}{*}{3} & 14 & - & - & - & - & - & - & - & - & - & - & - & - & - & - \\
\hline & 15 & - & - & - & - & - & - & - & - & - & - & - & - & - & - \\
\hline & 16 & - & - & - & - & - & - & - & - & - & - & - & - & - & - \\
\hline & 17 & - & - & - & - & - & - & - & - & - & - & - & - & - & - \\
\hline & 18 & - & - & - & - & - & - & - & - & - & - & - & - & - & - \\
\hline & 19 & - & - & - & - & - & - & - & - & - & - & - & - & - & - \\
\hline & 20 & - & - & - & - & - & - & - & - & - & - & - & - & - & - \\
\hline
\end{tabular}

Примітка: $\mathrm{Ct}$ - значення порогового циклу реакції, яке має прямо пропорційну залежність із кількістю цільової послідовності кДНК вірусу $P E D V$.

Отже, синдром діареї у неонатальних поросят першої дослідної групи був індукований міксінфекцією, яка складається з асоціації альфакоронавіpуса і E. coli, а у поросяти другої групи ентеральний розлад був обумовлений моноінфекцією $\beta$-гемолітичної E. coli на тлі відсутності PEDV.

3 кишечнику всіх дослідних і контрольних поросят не виділили фізіологічно корисної індигенной мікрофлори - аерококів, молочно-кислих- і біфідобактерій, а висіяли гнильну факультативно-анаеробну спорову i неспорову мікрофлору.

Інфекційна патологія з синдромом діареї альфакоронавірусної етіології $є$ емерджентним і високо контагіозним летальним захворюванням неонатальних поросят (Dastjerdi et al., 2015). Всі етапи боротьби і профілактики цієї інфекції пов'язані 3 серйозними методологічними труднощами, незважаючи на досить глибокі знання біології збудника. Основна проблема полягає в тому, що хворіють неонатальні поросята, абсолютно беззахисні перед інфектопатогеном, а засоби специфічної профілактики недостатньо ефективні. Своєчасна індикація вірусу ЕДС в навколишньому середовищі ускладнена і часто буває запізнілим заходом боротьби (Song and Park, 2012). Неонатальні поросята $є$ біоіндикаторами присутності вірусу в навко- лишньому середовищі, і спалах ентеральних розладів роблять лабораторну діагностику $P E D V$ - «fenomen post factum». Патогенез ентеральної патології включає експоненціальну репродукцію $P E D V$ в ентероцитах, їх загибель і десквамацію 3 подальшими елементами діарейного синдрому - водянистий профузний пронос, дегідратація, інтоксикація, мікробіальна експансія гнильної і гліколітичної мікробіоти з посилюванням токсичного впливу, нейрогуморальна загальноорганізмова супресія, метаболічний ацидоз, анорексія, i як наслідок сумарного впливу патофізіологічних чинників - летальний результат (Carvajal et al., 2015).

У складі віріона вірусу ЕДС є чотири види білків: S, E, M i N. Spike- i Envelope-протеїни забезпечують адгезію і злиття (сплав) ліпопротеїдних оболонок віріона і ентероциту, а матриксні і нуклеотидні білки, спільно зі структурним білком забезпечують розпаковування і репродукцію вірусу в ентероцитах (Song and Park, 2012). Порушення структури цих білків, яке може бути наслідком тривалого зберігання без кріопротекторів вище евтектичної зони негативних температур, призводить до деградації структури віріона, що обумовлює зниження рівня адгезії, проникнення i репродукції вірусу i, як наслідок, зниження вірулентності збудника. 
На секційній картині патогномонічною ознакою є дегенеративні зміни в ентероцитах, перш за все порожньої кишки, з розвитком атрофії та укороченням ворсинок і мікроворсинок. Десквамація ентероцитів мікроворсинок призводить до зменшення всмоктувальної функції поверхні тонкого кишечнику, що в сукупності з функціональними порушеннями і злущуванням значної кількості ентероцитів призводить до зниженого всмоктування і основного симптому інфектопатологіi - профузної водянистої діареї (Stevenson et al., 2013). Загибель поросят настає від сукупного впливу інтоксикації, ацидозу і дегідратації (Carvajal et al., 2015).

Підсумовуючи вищенаведене, треба відзначити, що на теперішній час не розроблені засоби специфічної терапії проти ЕДС, загибель неімунних поросят настає невідворотно, внаслідок швидкоплинності, незворотності і несумісного з життям лавиноподібного наростання шкідливого впливу емерджентного збудника на новонароджений організм під час постнатального переходу від внутрішньоутробного розвитку до існування у зовнішньому середовищі біологічно агресивного мікробного світу.

\section{Висновки}

1. Пероральне зараження неонатальних безмолозивних поросят смузі з тонкої кишки тварин, хворих на ЕДС, призводить до розвитку типової інфекційної патології, підтвердженої комплексним дослідженням, включаючи ідентифікацію PEDV методом PCR-RT. При цьому клінічна картина ЕДС виникла у 2317 заражених поросят, що пов'язане 3 інактивацією $P E D V$ при тривалому зберіганні вище евтектичної зони негативних температур і дефростації. Інфікування відбувалося на тлі колібактеріозної інфекції з порушенням фізіологічного балансу кишкової мікробіоти і превалюванням гнильних мікробіальних процесів.

2. Зберігання вірусу ЕДС у складі гомогенату 3 тонкого кишечнику загиблих від ЕДС поросят в нативному вигляді без кріопротекторів при $-18{ }^{\circ} \mathrm{C}$ до 359 діб є крайнім критичним терміном, оскільки кількість неушкодженого життєздатного вірусу ЕДС знижується до рівня мінімальної заражаючої дози і застосування гомогенату для зворотного згодовування стає малоефективним.

3. Кишкова мікрофлора неонатальних поросят, інфікованих $P E D V$, у процесі розвитку діарейного синдрому зазнає якісних і кількісних змін порівняно 3 нативним мікробіоценозом кишечнику здорових тварин. Індигенна нормофлора витісняється транзитор- ною банальною умовно-патогенною мікробіотою 3 високою ферментативною активністю протеолітичного і гліколітичного профілю з накопиченням токсичних гнильних продуктів проміжного розпаду. Пробіотична мікрофлора - аерококи, молочно-кислі- і біфідобактерії не ізольовані.

Перспективи подальиих досліджень. Подальше поглиблене вивчення етіопатогенезу діарейного синдрому в неонатальних поросят 3 мажорним інфектопатогеном $P E D V$. Визначення всіх співчленів паразитарного мікробіоценозу кишкової трубки і з'ясування етіопатогенетичної ролі збудників інфекційної патології кишкових асоціантів у взаємозв'язку між собою. Дуже важливим є вивчення біологічної активності та експериментальне визначення кількісної характеристики вірулентності, а також встановлення кореляційного якісного взаємозв'язку між вірулентними та імуногенними властивостями епізоотичного варіанту вірусу. 3 огляду на те, що всі біологічні явища детерміновані генетично, принципово важливим буде визначення нуклеотидного складу генома - секвенування, і на його основі з'ясування біологічної ролі молекулярних компонентів вірусу в індукції патогенетичних змін у чутливій клітинній системі організму неонатальних поросят як біологічної мішені для $P E D V$.

\section{Бібліографічні посилання}

Carvajal, A., Argüello, H., Martínez-Lobo, F.J.,Costillas, S., Miranda, R., de Nova, P.J.G., Rubio, P. (2015). Porcine epidemic diarrhoea: new insights into an old disease. Porcine Health Management. http://porcinehealthmanagement.biomedcentral.com/ar ticles/10.1186/s40813-015-0007-9

Dastjerdi, A., Carr, J., Richard, J. (2015). Porcine Epidemic Diarrehea Virus among Farmed Pigs, Ukraine. Emerging Infectious Disease. 21(12), 22352237. www.cdc.gov/eid.

Song, D., Park, B. (2012). Porcine Epidemic Diarrhea Virus, a comprehensive review of molecular epidemiology, diagnosis and vaccines. Virus Genes. 44, 167-175

Stevenson, G.W., Hoang, H., Schwartz, K.J. (2013). Emergence of Porcine epidemic diarrhea virus in the United States: clinical signs, lesions and viral genomic sequences. J. Vet Diagn. Invest. 25, 649-654. http://dx.doi. org/10.1177/1040638713501675

Sait Mizhnarodnoho Epizootychnoho Biuro. Rezhym dostupu: http://www.oie.int/en (in Ukrainian).

Стаття надійшла до редакиії 31.03.2017 